\title{
An evaluation of the antimicrobial synergy of Garlic (Allium sativum) and Utazi (Gongronema latifolium) on Escherichia coli and Staphylococcus aureus
}

\author{
Eja, M. E. ${ }^{*}$ Arikpo, G. E., Enyi-Idoh K. H. and Ikpeme, E. M. \\ Department of Biological Sciences, Cross River University of Technology, Calabar, Nigeria. \\ E-mail: mattheweja2000@yahoo.com \\ Received 27 March 2010; received in revised form 12 July 2010; accepted 27 July 2010
}

\begin{abstract}
As part of the on-going search for potent and resistance-free antimicrobial medicinal plants, the antimicrobial and synergistic effects of the plants, Allium sativum (E1) and Gongronema latifolium (E2) on Escherichia coli and Staphylococcus aureus were investigated. The sensitivities of $E$. coli and $S$. aureus to $\mathrm{E} 1$ and $\mathrm{E} 2$ and the minimum inhibitory concentrations of the plant extracts, individually and in combination with themselves, and with ciprofloxacin (CPX) and ampicillin (AMP), were tested using standard procedures. E1 and E2 individually showed appreciable antimicrobial effect (zones of inhibition $\geq 16 \mathrm{~mm}$ ). The combination of $E 1$ and $E 2$ against the test organisms was not effective due to antagonism between E1 and E2. E1 or E2 when combined with CPX, completely suppressed the effect of CPX against $E$. coli, and rather produced additive effect on $S$. aureus similar to the combination of E2 and AMP against $S$. aureus, although CPX alone was more effective than either E1 or E2, unlike AMP. Synergism was observed in the combination of E1 and AMP against $S$. aureus. It is concluded that synergism associated with the combination of medicinal plants is doubtful. However, the synergistic or additive effect between garlic and conventional drugs to some strains of bacteria which are resistant to some conventional drugs, gives hope of fighting drug resistance.
\end{abstract}

Keywords: antimicrobial effect, synergism, Allium sativum, Gongronema latifolium, ciprofloxacin, ampicillin

\section{INTRODUCTION}

Garlic (Allium sativum) in the family Liliaceae is a perennial bulb-forming plant. It is known world-wide, and for several centuries, it has been used for dietary and medicinal purposes (Ross et al., 2001). Gongronema latifolium, of the family Asclepiadaceae (locally called utazi in the Igbo dialect of Nigeria), is a climber with woody hollow glabrous stems below, and characterized by greenish yellow flowers. The leaves of the plant are used as spice and as medicine in West Africa.

Several studies have confirmed that garlic has antimicrobial properties (Reuter et al., 1996; Martin and Ernst, 2003; Eja et al., 2007). On the other hand, not much work has been carried out to investigate the antimicrobial activity of $G$. latifolium. One such successful research, among a few others, was reported by Oshodi et al. (2004) on the antimicrobial activity of aqueous extracts of Vernonia amygdalina, Garcinia kola, and G. latifolium and their blends, on some beer spoilage organisms. The application of blends was based on the concept of the effectiveness of combination therapy (synergism) in the treatment of certain bacterial infections involving drug resistant organisms (Weinstein, 1975; Mitchel et al., 1977; Duncan et al., 1980). Garlic has even been noted to act synergistically with antibiotics (Sivam et al., 1997); and no similar specific report has been made on $G$. latifolium. Recently, however, Lasianthera africana or Heinsia crinata in combination with chloramphenicol, has been observed to have synergistic effect on Candida albicans (Andy et al., 2008).

However, synergic treatment of ailments has been a long aged practice in both orthodox and traditional medicines. In Sub-saharan Africa, especially West Africa, including Ghana and Nigeria, herbal medicines are believed to be more effective when taken in combination. In particular, herbal medicines taken orally are combined and immersed in locally brewed gin for a short period of time for effective extraction of the active ingredients of the herbs. The gin extracts of the herbs are taken in homes, or sold in wine bars as medicines against some ailments.

The aim in this study was to assess the antimicrobial activity of garlic extract compared to that of the less widely known G. latifolium in parallel with ciprofloxacin and ampicillin as control, against known bacterial pathogens such as Escherichia coli and Staphylococcus aureus. The antimicrobial activity of the extracts against the organisms was also to be tested in combination with themselves and with the controls (ciprofloxicin and ampicillin).

\section{MATERIALS AND METHODS}

\section{Source of test organisms and plants}

Known cultures of $E$. coli and $S$. aureus were obtained from the Department of Medical Microbiology and Parasitology of the University Teaching Hospital, Calabar. The two test plants, garlic and utazi, were bought directly 
from women who are the main sellers of spices at Calabar Central Market.

\section{Preparation and concentrations of the garlic and utazi extracts}

The garlic cloves were peeled, cut into pieces, and $20 \mathrm{~g}$ was put in a juice extractor to squeeze out the raw garlic extract. Utazi was pounded in a clean mortar and the raw extract was squeezed out.

Each of the extracts $(10.5 \mathrm{~mL})$ was placed in a preweighed glass dish and reweighed, followed by drying in an oven at $60{ }^{\circ} \mathrm{C}$. The difference between the weights of each of the extracts before and after drying, was taken as the weight of the active component of the extracts which could have evaporated. The weights obtained for garlic (Eja et al., 2007) and utazi extracts were $1.12 \mathrm{mg}$ and $1.21 \mathrm{mg}$ respectively, equivalent to 106.7 and 115.2 $\mathrm{mg} / \mathrm{mL}$.

Thus, from the raw garlic and utazi extracts, dilutions of $1: 2,1: 4,1: 8,1: 16,1: 32$ and $1: 64$ in deionised water, corresponding to $35.6,21.3,11.8,6.3,3.2,1.6 \mathrm{mg} / \mathrm{mL}$ for garlic, were made, while the corresponding weights for utazi were $38.2,23.0,12.8,6.8,3.5$ and $1.8 \mathrm{mg} / \mathrm{mL}$. These were calculated based on the ratios. For instance, $1: 2$ resulted in $1 / 3 \times 106.7 \mathrm{mg} / \mathrm{mL}$, and so on to $1: 64$ which gave $1 / 65 \times 106.7=1.6 \mathrm{mg} / \mathrm{mL}$. These dilutions were used for the minimum inhibitory concentration (MIC) test.

\section{Testing for antimicrobial effects of raw garlic and utazi extracts}

A disc diffusion technique using the Kirby-Bauer method (Prescott et al., 2005) was applied in testing pure cultures of the isolates for their antimicrobial sensitivities.

The sensitivity discs used for the test were punched from Whatman No. 1 filter paper. The discs were $5 \mathrm{~mm}$ in diameter. After sterilization, the discs were impregnated with the raw extracts of garlic and utazi separately (Onyeaba et al., 2004). Five agar plates for each test organism per plant extract were inoculated with $0.1 \mathrm{~mL}$ broth culture of test organisms and spread with a glass rod shaped like a hockey stick, and incubated at $37^{\circ} \mathrm{C}$ for $24 \mathrm{~h}$. The antibiotics, ampicillin (AMP) and ciprofloxacin (CPX), were used as controls for comparison with the raw extracts. The plates were observed for zones of inhibition after incubation followed by calculation of the mean zones of inhibition (mm).

\section{Testing for MIC of the extracts}

The MIC was determined by first preparing a standard inoculum. This involved transferring a portion of the pure culture of each isolate into tryptone soya broth (Oxoid CM129) and incubating at room temperature overnight. The overnight broth culture $(0.1 \mathrm{~mL})$ was diluted with $1 \mathrm{~mL}$ of distilled water in the ratio of 1:100 to give a final dilution of $10^{-3}$ of the standard inoculum (Adoum et al.,1997) following which the dilution susceptibility test technique (Prescott et al., 2005) was applied. The reciprocal of $10^{-3}$ equivalent to $10^{3}$ was the number of organisms in the standard inoculums used for the MIC test. In this technique, the previously prepared Mueller-Hinton broth containing various concentrations of the extracts of the plants was inoculated with the standard inoculum. This was done for each of the test organisms followed by incubation at $37^{\circ} \mathrm{C}$ for $16-20 \mathrm{~h}$. The presence or absence of growth for each concentration was recorded at the end of incubation. The lowest concentration of the extracts resulting in no growth after $16-20 \mathrm{~h}$ of incubation was taken as the MIC. The same treatment was given to the combination of the extracts of the two plants and those of the individual extracts.

\section{Synergy test}

To test the combined extracts, equal volumes $(0.1: 0.1)$ were mixed and the mixture was tested with the individual extracts separately.

To carry out a combination test of the extracts with the controls (CPX and AMP), 106.7 and $115.2 \mathrm{mg}$ of CPX and AMP respectively, were each dissolved in $1 \mathrm{~mL}$ of deionized water, so that the initial concentrations of the controls were the same as those of the raw extracts. Thus, to test the extracts combined with CPX and AMP, equal volumes of the extracts and the controls $(0.1: 0.1)$ were mixed and the mixture was tested along with the individual extracts and controls separately (Andy et al., 2008).

\section{RESULTS}

Table 1 represents the effect of the extracts of $A$. sativum (E1) and G. latifolium (E2) on E. coli and S. aureus. The zones of inhibition produced by $E 1$ and $E 2$ were more than $15 \mathrm{~mm}$ indicating appreciable antimicrobial activity against the test organisms. In the combination of E1 and $E 2$, the effect of E2 on E. coli was completely antagonized or masked by that of $E 1$. With respect to $S$. aureus, there was antagonism between E1 and E2 resulting in a lower combination effect (13 $\mathrm{mm}$ zone of inhibition) than either $\mathrm{E} 1$ or E2. E2 antagonized E1 but not completely. The table shows that CPX was more effective than E1 or E2 against both $E$. coli and $S$. aureus. AMP was rather less effective than the plants, and $S$. aureus was especially resistant to AMP.

The effect of the combination of the plant extracts with conventional antibiotics, CPX and AMP is represented in Tables 2 and 3 . CPX was completely antagonized by $\mathrm{E} 1$ and $\mathrm{E} 2$ in their combined effect on $E$. coli. On the other hand, the combination of CPX with E1 produced additive effect on $S$. aureus, while E2 partially antagonized CPX (Table 2).

However, the combination of AMP with E1 showed additive effect on $E$. coli and synergistic effect on $S$. aureus as shown in Table 3. On the effect of the combination E2 + AMP against the test organisms, there was additive effect between E2 and AMP on E. coli (Table 3) and antagonism between AMP and E2 on $S$. aureus. The combination of the MIC of E1 and E2 on the test 
Table 1: Effect of raw extracts of $A$. sativum (E1) and $G$. latifolium (E2) on the test organisms

\begin{tabular}{lccccl}
\hline \multirow{2}{*}{ Test organisms } & \multicolumn{6}{c}{$\begin{array}{c}\text { Mean zones of } \\
\text { inhibition }(\mathrm{mm})\end{array}$} \\
\cline { 2 - 6 } & $\mathrm{E} 1$ & $\mathrm{E} 2$ & $\mathrm{E} 1+\mathrm{E} 2$ & $\mathrm{CPX}$ & $\mathrm{AMP}$ \\
\hline $\begin{array}{l}\text { Escherichia coli } \\
\begin{array}{l}\text { Staphylococcus } \\
\text { aureus }\end{array}\end{array}$ & 18 & $19^{\mathrm{a}}$ & 13 & 38 & $0^{*}$ \\
\hline
\end{tabular}

* Staphylococcus aureus was resistant to ampicillin.

${ }^{a}$ E1 completely antoganized E2; b = E2 antagonized E1 resulting in a lower figure of $13(E 1+E 2)$.

Table 2: Effect of raw extracts of $A$. sativum (E1), G. latifolium (E2) and ciprofloxacin (CPX) on the test organisms

\begin{tabular}{lccccc}
\hline & \multicolumn{6}{c}{$\begin{array}{c}\text { Mean zones of } \\
\text { inhibition }(\mathrm{mm})\end{array}$} \\
\cline { 2 - 6 } Test organisms & $\mathrm{E} 1$ & $\mathrm{E} 2$ & $\mathrm{CPX}$ & $\begin{array}{c}\mathrm{E} 1+ \\
\mathrm{CPX}\end{array}$ & $\begin{array}{c}\mathrm{E} 2+ \\
\mathrm{CPX}\end{array}$ \\
\hline $\begin{array}{l}\text { Escherichia coli } \\
\begin{array}{l}\text { Staphylococcus } \\
\text { aureus }\end{array}\end{array}$ & $19^{\mathrm{a}}$ & $17^{\mathrm{b}}$ & 30 & 19 & 17 \\
\hline
\end{tabular}

${ }^{\mathrm{a}} \mathrm{E} 1$ completely antagonized $\mathrm{CPX}$ to result in $19(\mathrm{E} 1+\mathrm{CPX})$.

${ }^{\mathrm{b}}$ E2 completely antagonized CPX to result in 17 (E2 + CPX).

Table 3: Effect of raw extracts of $A$. sativum (E1), G. latifolium (E2) and ampicillin (AMP) on the test organisms

\begin{tabular}{|c|c|c|c|c|c|}
\hline \multirow{2}{*}{ Test organisms } & \multicolumn{3}{|c|}{$\begin{array}{l}\text { Mean zones of } \\
\text { inhibition }(\mathrm{mm})\end{array}$} & \multirow[b]{2}{*}{$\begin{array}{l}\mathrm{E} 1+ \\
\mathrm{AMP}\end{array}$} & \multirow[b]{2}{*}{$\begin{array}{l}\text { E2 + } \\
\text { AMP }\end{array}$} \\
\hline & E1 & E2 & AMP & & \\
\hline \multirow{2}{*}{$\begin{array}{l}\text { Escherichia coli } \\
\text { Staphylococcus } \\
\text { aureus }\end{array}$} & 19 & 17 & 13 & 21 & 18 \\
\hline & 18 & $16^{c}$ & $0^{*}$ & 23 & 10 \\
\hline
\end{tabular}

* Staphylococcus aureus was resistant to ampicillin.

${ }^{\mathrm{C}} \mathrm{E} 2$ was antagonized by AMP.

Table 4: The minimum inhibitory concentration (MIC) of $A$. sativum (E1) and $G$. latifolium (E2) singly and in combination on the test organisms

\begin{tabular}{llll}
\hline \multirow{2}{*}{ Test organisms } & \multicolumn{3}{l}{$\mathrm{MIC}(\mathrm{mg} / \mathrm{mL})$} \\
\cline { 2 - 4 } & $\mathrm{E} 1$ & $\mathrm{E} 2$ & $\mathrm{E} 1+\mathrm{E} 2$ \\
\hline $\begin{array}{l}\text { Escherichia coli } \\
\text { Staphylococcus }\end{array}$ & 3.2 & 6.3 & 3.2 \\
\begin{tabular}{l} 
aureus \\
\hline
\end{tabular} & 11.8 & 21.3 & 15.6 \\
\hline
\end{tabular}

Figures represent means of two readings obtained from the dilutions of E1 $(106.7 \mathrm{mg} / \mathrm{mL})$ and $E 2(115.2 \mathrm{mg} / \mathrm{mL})$ from $1: 2$ to $1: 64$. organisms produced antagonistic effect on both $E$. coli and $S$. aureus (Table 4). E1 completely masked the effect of E2 against $E$. coli, but partially antagonized E2 in the case of $S$. aureus.

\section{DISCUSSION}

Results obtained in this study have revealed that $A$. sativum and $G$. latifolium have very high antimicrobial activity (mean zone of inhibition $\geq 16 \mathrm{~mm}$ ) against the test organisms, E. coli representing the group of gram negative enteric bacterial pathogens, and $S$. aureus representing the group of gram positive bacterial pathogens. Of course, it has been reported and established that $A$. sativum has antimicrobial potency (Cai et al., 2007; Eja et al., 2007). There are reports on the antimicrobial activity of $A$. sativum against diarrhoeagenic pathogens, e.g., E. coli, and wound pathogens, such as $S$. aureus (Tessema et al., 2006; Eja et al., 2007). The antimicrobial activity of the garlic has been attributed to its phytochemical component, allicin (a thiosulfonate) whose removal completely renders garlic ineffective against microorganisms (Hughes and Lawson, 1991; Cai et al., 2007).

However, not much research has been carried out on the antimicrobial property of $G$. latifolium which has been used for ages by the people of West Africa including Nigeria, for dietary and medicinal purposes. The antimicrobial activity revealed in this study had been reported in an earlier study (Oshodi et al., 2004). The phytochemical composition of $G$. latifolium has been reported to consist of about $0.5 \%$ flavonoids, $2 \%$ tannins, $0.66 \%$ saponins, $0.33 \%$ polyphenols, $1.97 \%$ alkaloids and $13.2 \%$ hydrogen cyanide (Atangwho et al., 2009). The presence of tannins, alkaloids, flavonoids, saponins and polyphenols could have been responsible for the antibacterial activity of $G$. latifolium. Elsewhere it is reported that tannins, alkaloids, saponins, flavonoids and glycosides could be associated with the antimicrobial activities of some Nigerian plants (Andy et al., 2008; Ibrahim et al., 2009). Of course, Farombi (2003) has noted that the active components of some of the Nigerian medicinal plants reside in the phytochemical components mentioned above. What has not been resolved is the separation of the specific bioactive components against specific organisms; and this has been noted to affect the quality and safety of herbal medicines (Sane, 2002).

In the combination of the extracts of $A$. sativum (E1) and $G$. latifolium (E2), it is apparent that there is greater effectivity using $A$. sativum alone for the treatment of infections associated with the two test organisms. A similar pattern of effect was observed in the combination of the extracts of the test plants with CPX and AMP. It is not known why CPX alone was more effective than garlic in this study, whereas it is the opposite in an earlier study (Eja et al., 2007). This could have been attributed to the differences in the concentrations of garlic and CPX used in the two separate studies.

This study reveals that the combination of garlic and utazi may not always yield the desired effect on both 
Gram positive and Gram negative bacteria, as there is evidence of antagonism among the plants, even in combination with conventional drugs. There is an indication therefore, that the antimicrobial effect of very highly active chemotherapeutic drug could be suppressed or masked when taken together with some medicinal plants. This agrees with the findings of Andy et al. (2008). The antagonistic effect is more evident when the combination is used on Gram negative organisms, e.g. $E$. coli. There is promise of desired effect when the combinations are used on Gram positive bacteria, e.g. $S$. aureus, in which case, the effect may be additive or synergistic. Additive effect as applied in this study means an enhanced effect produced by the combination of two or more plant extracts, or extracts combined with conventional drugs. The effect is antagonistic when one plant suppresses the effect of the other resulting in a diminished effect, and synergistic when the elevated effect potentially destroys a resistant organism, as experienced in the effect of the combination of garlic and AMP against $S$. aureus in this study.

Similar findings are available (Andy et al., 2008). However there were conflicting reports on the combined effects of $V$. amygdalina, $G$. kola and $G$. latifolium on some microbial species, including $E$. coli and $S$. aureus in a study of the antimicrobial activity of Nigerian medicinal plants potentially usable as hop substitute (Oshodi et al., 2004). In the report (Oshodi et al., 2004), G. latifolium appeared to have little or no effect on $E$. coli, but the combination of G. latifolium, G. kola and V. amygdalina had high effect on E. coli, S. aureus and Streptococcus salivarus. Apparently, high concentrations were used besides combining three plant extracts. Even then, the report of Oshodi et al. (2004) did not deviate much from the findings of this study.

\section{CONCLUSIONS}

It is concluded that $A$. sativum and $G$. latifolium individually possess relatively high antimicrobial activity against $E$. coli and $S$. aureus. However, the combined effects of the plant extracts on these organisms are in doubt especially as the factors of antagonism and or additive effects are not yet properly elucidated. What is apparent is the synergism between AMP and garlic on $S$. aureus which was noted to be completely resistant to AMP. The synergism observed in this study is attractive in view of the current problem of drug resistance by microorganisms and the fact that the modes of action of garlic and ampicillin (i.e. inhibition of cell wall synthesis) are similar (Prescott et al., 2005; Eja et al., 2007).

\section{REFERENCES}

Adoum, O. D., Dabo, N. T. and Fatope, M. O. (1997). Bioactivities of some savanna plants in the brine shrimp lethality test and in vitro antimicrobial assay. International Journal of Pharmacology 5,334-337.

Andy, I. E., Eja, M. E. and Mboto, C. I. (2008). An evaluation of the antimicrobial potency of Lasianthera africana (BEAUV) and Heinsia crinata (G. Taylor) on Escherichia coli, Salmonella typhi, Staphylococcus aureus and Candida albicans. Malaysian Journal of Microbiology 4(1), 25-29.

Atangwho, I. J., Ebong, P. E., Eyong, E. U., Williams, I. O., Eteng, M.U. and Egbung, G. E. (2009). Comparative chemical composition of some antidiabetic medicinal plants: Azadirachta indica, Vernonia amygdalina and Gongronema latifolium. African Journal of Biotechnology 8, 4685-4689.

Cai, Y., Wang, R., Pei, F. and Liang, B. B. (2007). Antimicrobial activity of allicin alone and in combination with beta-lactams against Staphylococcus spp. and Pseudomonas aeruginosa. Journal of Antibiotics 60, 335-338.

Duncan, M. E., Perine, P. C., Krause, D. W., Awoke, S. and Zaidi, A. A. (1980). Pelvic inflammatory disease and puerperal sepsis in Ethiopea II: Treatment. American Journal of Obstetrics and Gynaecology 138, 1059-1063.

Eja, M. E., Asikong, B. E., Abriba, C., Arikpo, G. E., Anwan, E. E. and Enyi-Idoh, K. H. (2007). A Comparative Assessment of the Antimicrobial Effects of Garlic (Allium sativum) and Antibiotics on Diarrhoeagenic organisms. Southeast Asian Journal of Tropical Medicine and Public Health 38. 343-348.

Farombi, E. O. (2003). African indigenous plant with chemotherapeutic potentials and biotechnological approach to the production of bioactive prophylacudiestic agents. African Journal of Biotechnology 2, 662-671.

Hughes, B. G. and Lawson, L. D. (1991). Antimicrobial effects of Allium sativum L. (garlic), Allium ampeloprasum (elephant garlic) and Allium cepa $L$. (onion), garlic compounds and commercial garlic supplement products. Phytotherapeutic Research 5, 154-158.

Ibrahim, T., Ajala, L., Adetuyi, F. and Jude-Ojei, B. (2009). The antimicrobial activity of Vernonia amygdalina and Occimum gratissimum leaves on selected food-borne pathogens. The Internet Journal of Third World Medicine 8, 1-8.

Martin, K. W. and Ernst, E. (2003). Herbal medicines for treatment of bacterial infections: A review of controlled clinical trials. Journal of Antimicrobial Chemotherapy 51, 241-246.

Mitchel, J., Jacobs, J. and Sacks, T. (1977). Bactericidal synergistic effect due to chloriamphenicol induced inhibition of Staphylococcal penicillinase. Chemotherapy 23, 32-36.

Onyeagba, R. A. Ugbogu, O. C., Okeke, C. U. and Iroakasi, O. (2004). Studies on the antimicrobial effects of garlic (Allium sativum Linn), Ginger (Zingiber officinale Roscoe) and lime (citrus aurantifolia Linn). African Journal of Biotechnology 3, 552-554.

Oshodi, A. A., Ameo, I. A. and Eleyinmi, A. F. (2004). Antimicrobial activity of aqueous extracts of Vernonia amygdalina, Garcinia kola and Gongronema latifolium and their blends on some beer spoilage organisms. 
Technical Quarterly of the Master Brewer's Association of the Americas 41, 398-402.

Prescott, L. M., Harley, J. P. and Klein, D. A. (2005). Microbiology. $6^{\text {th }}$ edn. McGraw-Hill, Boston. pp. 992.

Reuter, H. D., Koch, H. P. and Lawson, L. D. (1996). Therapeutic effects and application of garlic and its preparations. In: Garlic. The science and therapeutic of Allium sativum L. and related species. Koch, $\mathrm{H}$. P. and Lawson, L. D. (eds.). Williams and Wilkins, Baltimore. pp. 135-212.

Ross, Z. M., O' Gara, E. A., Hill, D. J., Sleightolme, H. V. and Maslin, I. J. (2001). Antimicrobial properties of garlic oil against human enteric bacteria: Evaluation of methodologies and comparisons with garlic oil, sulfides and garlic powder. Applied Environmental Microbiology 67, 475-480.

Sane, R. T. (2002). Standardization, quality control and GMP for herbal drugs. Indian Drugs 39, 184-189.

Sivam, G. P., Lampe, J. W., Ulness, B., Swanzy, S. R., and Potter, J. D. (1997). Helicobacter pylori-in vitro susceptibility to Garlic (Allium sativum) extract. Nutritional and Cancer 27, 118-121.

Tessema, B., Mulu, A., Kassu, A. and Yismaw, G. (2006). An in vitro assessment of the antimicrobial effect of garlic (Allium sativum) on bacterial isolates from wound infections. Ethiopian Medical Journal 44, 385-389.

Weinstein, L. (1975). Antimicrobial Agents Penincillins and Cephalosporins. The Pharmaceutical Basis of Therapeutics. $5^{\text {th }}$ edn. Macmillan C, New York. pp. 1130-1160. 